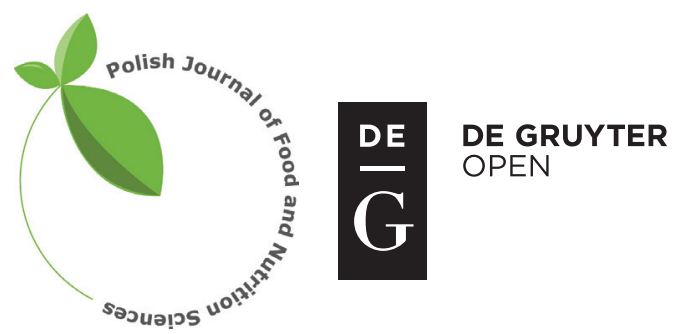

Pol. J. Food Nutr. Sci., 2018, Vol. 68, No. 2, pp. 179-186

DOI: $10.1515 /$ pjfns-2017-0026 http://journal.pan.olsztyn.pl

Original research article

Section: Food Quality and Functionality

\title{
Vitamin C, Phenolic Compounds and Antioxidant Capacity of Broccoli Florets Grown under Different Nitrogen Treatments Combined with Selenium
}

\author{
Elena Peñas ${ }^{1}$, Danuta Zielińska², Piotr Gulewicz ${ }^{3}$, Henryk Zieliński ${ }^{4}$, Juana Frias $^{1 *}$ \\ ${ }^{1}$ Institute of Food Science, Technology and Nutrition (ICTAN-CSIC), Juan de la Cierva 3, 28006 Madrid, Spain \\ ${ }^{2}$ University of Warmia and Mazury, Department of Chemistry, Olsztyn, Poland \\ ${ }^{3}$ Adam Mickiewicz University Foundation, Poznań Science and Technology Park, Poznań, Poland \\ ${ }^{4}$ Institute of Animal Reproduction and Food Research, Polish Academy of Sciences, Olsztyn, Poland
}

Key words: bioactive compounds, broccoli, nitrogen, selenium

Broccoli consumption is rising worldwide and fertilization is a tool to increase its production. However, little is known about the effect of mineral supplementation to the soil on the bioactive compounds. Therefore, the aim of this investigation was to analyze the content of vitamin $\mathrm{C}$, total phenolic compounds and the antioxidant capacity of broccoli florets cultivated under different nitrogen $(\mathrm{N})$ conditions in combination with selenium (IV and VI). Greenhouse experiments were conducted in broccoli grown in commercial soil treated with different $\mathrm{N}$ sources $\left[\left(\mathrm{NH}_{4}\right)_{2} \mathrm{SO}_{4}, \mathrm{NaNO}_{3}\right.$, $\mathrm{NH}_{4} \mathrm{NO}_{3}$ or $\mathrm{CO}\left(\mathrm{NH}_{2}\right)_{2}$ at $160 \mathrm{~kg} \mathrm{~N} / \mathrm{ha}$ ]. In addition, selenium (Se) salts $\left[\mathrm{Na}_{2} \mathrm{SeO}_{3}(\mathrm{Se} \mathrm{IV})\right.$ or $\mathrm{Na}_{2} \mathrm{SeO}_{4}(\mathrm{Se} \mathrm{VI})$ at 10 and $20 \mathrm{~kg} \mathrm{Se} / \mathrm{ha}$ ] were applied. There were no evidences of the influence of $\mathrm{N}$ treatment on vitamin $\mathrm{C}$ content whilst Se (IV or VI) uptake led to a significant reduction of this vitamin in broccoli florets, irrespective of the $\mathrm{N}$ source. In contrast, total phenolics content and antioxidant capacity underwent a significant increment under $\mathrm{N}$ application. However, their combination with Se salts modified total phenolic content and antioxidant capacities in broccoli florets depending on $\mathrm{N}$ source and Se doses. Among all the experimental trials, application of $\mathrm{NH}_{4} \mathrm{NO}_{3}$ combined with $10 \mathrm{~g} \mathrm{Se}$ (IV)/ha was the elective treatment strategy to produce broccoli florets with higher content of phenolic compounds and antioxidant capacity and, therefore, enhanced functionality.

\section{INTRODUCTION}

The interest of consumers in health and their knowledge on the relationship between diet and well-being is on the rise. Brassicaceae family is one of the most healthy recognized plant foods since their consumption has been linked to a reduction of the risk of a number of cancers [Avato \& Argentieri, 2015; Talalay \& Fahey, 2001]. Among brassicas, broccoli ( $B$. oleracea L. var. botrytis) takes an outstanding position and its consumption has increased sharply from $0.6 \mathrm{~kg}$ per capita in the 80 s to almost $3.5 \mathrm{~kg}$ per capita nowadays in the U.S. [USDA, 2015].

Broccoli is considered as an integral part of a healthy diet as a good source of biologically-active compounds [Jeffery \& Araya, 2009]. In this sense, broccoli is an excellent source of nitrogen-sulphur derivatives (glucosinolates and isothiocyanates), phenolics (chlorogenic and sinapic acid derivatives, and flavonols), and essential micronutrients (vitamins and minerals) exhibiting antioxidant and cancer chemopreventive properties [Guerrero-Beltran et al., 2012; Talalay \& Faley, 2001]. Broccoli also provides lutein and zeaxanthin [Manzi et al., 2002] and is one of the greatest contributors to

\footnotetext{
* Corresponding Author: Tel.: +34912587510; Fax: +34915644853

E-mail: frias@ictan.csic.es (Prof. J. Frias)
}

folate, vitamin $\mathrm{C}$ and phenolic compounds intakes [Domínguez-Perles et al., 2014; McKillop et al., 2002]. Vitamin C and phenolic compounds play an important role as antioxidants, inhibiting oxidative damage involved in coronary heart disease and stroke [Moreno et al., 2006; Proteggente et al., 2002].

The productivity and nutritional and functional quality of broccoli can be enhanced by mineral treatment [Abou ElMagd et al., 2010; Omirou et al., 2009] and the addition of N, $\mathrm{P}, \mathrm{K}$ and $\mathrm{S}$ to the soil generally increases crop yield as well as phytochemical content [Michalska et al., 2016], however, excessive fertilizer concentration can result in decreases of vitamin $\mathrm{C}$, soluble sugars, soluble solids, $\mathrm{Mg}$ and $\mathrm{Ca}$ in some crops [Wang et al., 2008]. In Chinese cabbage, enrichment with $\mathrm{N}$ provided in rates $>180 \mathrm{Kg} /$ ha resulted in lower content of vitamin C, nitrates, soluble solids, total solids and sugars [Staugaitis et al., 2008]. In broccoli plants, the growth status and glucosinolates concentration responded successfully to the $\mathrm{N}$ treatment at $200 \mathrm{~kg} / \mathrm{ha}$ [Omirou et al., 2009].

Selenium (Se) plays an important physiological role in the integrity of antioxidant enzymes in plants involved in protection against many types of stress, environmental and induced ones [Harris, 1992]. For humans, Se is a key trace element with important implication in nutrition and health [Rayman, 2008]. This micronutrient is usually deficient in some European areas [Ducsay et al., 2009] and Se-fortifi- 
cation has been suggested as an effective strategy to improve Se intake [Pedrero et al., 2007; Peñas et al., 2012]. Broccoli has the ability to accumulate Se as Se-methyl selenocysteine (SeMSeC) [Lyi et al., 2005], an amino acid derived compound that has been linked with cancer prevention [Finley, 2003]. However, the application of different Se salts differs in their bioavailability owed to their different sorption ability in the soil. Among inorganic Se forms, Se (IV) uptake was higher than Se (VI) by lupin sprouts and broccoli that exhibited improved total antioxidant capacity [Mahn et al., 2012; Zielinska et al., 2008a]. Additionally, the application of Se (IV) in broccoli regulated plant water status under drought conditions [Germ et al., 2007] and increased glucosinolate content [Robbins et al., 2005]. Moreover, Se-enriched white clovers showed larger antioxidant ability to scavenge free radicals with Se (VI) supply [Mora et al., 2008].

Although relevant information has been found on the impact of mineral fortification on the quality and content of some bioactive compounds, to our knowledge no data are available concerning the combined effects of different $\mathrm{N}$ supply and Se salts on vitamin $\mathrm{C}$, total phenolics and antioxidant capacity of broccoli florets. Therefore, the aim of the present study was to evaluate the influence of various $\mathrm{N}$ inorganic forms applications $\left[\left(\mathrm{NH}_{4}\right)_{2} \mathrm{SO}_{4}, \mathrm{NaNO}_{3}, \mathrm{NH}_{4} \mathrm{NO}_{3}\right.$ and $\left.\mathrm{CO}\left(\mathrm{NH}_{2}\right)_{2}\right]$ combined with Se (IV) and Se (VI) salts on the content of these health-promoting compounds. The outcomes will guide to establish the source of $\mathrm{N}$ and Se to achieve broccoli florets with enhanced biologically-active properties.

\section{MATERIAL AND METHODS}

\section{Chemicals}

Azino-bis-(3-ethylbenzothiazoline-6-sulfonic acid) diammonium salt (ABTS), 6-hydroxy-2,5,7,8-tetramethylchroman2-carboxylic acid (Trolox), (+)-catechin, metaphosphoric acid, isoascorbic and ascorbic acid standards, DL-dithiotreitol and selenium IV and VI salts $\left(\mathrm{Na}_{2} \mathrm{SeO}_{3}\right.$ and $\mathrm{Na}_{2} \mathrm{SeO}_{4}$, respectively) were supplied by Sigma-Aldrich (Sigma-Aldrich, Steinheim, Germany). Photochemiluminescence analytical kit for measurement of the antioxidant capacity (kit No. 400.801) was supplied by Analytik Jena AG (Jena, Germany). All nitrogen fertilizers, Folin-Ciocalteu reagent and sodium carbonate $\left(\mathrm{Na}_{2} \mathrm{CO}_{3}\right)$ were purchased from POCh, Gliwice (Poland). Water was purified using the Milli-Q-system (Millipore, Bedford, USA).

\section{Greenhouse experiments}

Commercial soil "Pokon" was purchased in enterprise Victus IT S.S Poznań (Poland). The soil was free from excess of $\mathrm{N}$ inorganic forms and it was composed by a mix of high sphagnum peat containing $6 \mathrm{~kg} \mathrm{CaCO} / \mathrm{m}^{3}$ and multicomponent mineral fertilizer with micronutrients dose of $1 \mathrm{~kg} / \mathrm{m}^{3}$. The $\mathrm{pH}$ of commercial soil ranged from 5.0 to 6.0. Seeds of broccoli (Brassica oleracea var. botrytis cv. Calabrese) were purchased in a seed market PPHU-Ogrodnik in Poznań, Poland. Broccoli seeds were disinfected with $1.5 \%$ sodium hypochloride and the soil was autoclaved before sowing. Single broccoli seeds were sown in $5 \mathrm{dm}^{3}(\varnothing 22 \mathrm{~cm})$ pots filled with commercial soil. The experiments were carried in a greenhouse with the commercial soil and different solid nitrogen sources $\left[\left(\mathrm{NH}_{4}\right)_{2} \mathrm{SO}_{4}, \mathrm{NaNO}_{3}, \mathrm{NH}_{4} \mathrm{NO}_{3}, \mathrm{CO}\left(\mathrm{NH}_{2}\right)_{2}\right]$ at $160 \mathrm{~kg}$ $\mathrm{N} /$ ha. Se salts $\left(\mathrm{Na}_{2} \mathrm{SeO}_{3}\right.$ and $\left.\mathrm{Na}_{2} \mathrm{SeO}_{4}\right)$ in aqueous solution at 10 or $20 \mathrm{~g} \mathrm{Se} /$ ha were administrated the first day of the experiment. Broccoli experiments are collected in Table 1.

During broccoli growth, greenhouse air humidity was kept at $60-70 \%$ and natural light was used. The temperature was kept at $18-20^{\circ} \mathrm{C}$ in the first month and at $22-24^{\circ} \mathrm{C}$ for the subsequent 3 months. Compact, hard and properly formed florets with undeveloped flower buds were collected after 4 months. Immediately after harvest, broccoli florets were freeze-dried, ground and kept in vacuum-welded bags at $-20^{\circ} \mathrm{C}$ for further analysis. Every single plant experiment was performed in quintuplicate.

\section{Determination of vitamin $C$ content}

The quantification of vitamin $\mathrm{C}$ in broccoli samples was carried out by micellar electrokinetic capillary electrophoresis (MECC) [Frias et al., 2005] following modifications: $0.5 \mathrm{~g}$ of freeze-dried broccoli sample were extracted with $20 \mathrm{~mL}$ of $3 \%$ metaphosphoric acid, and after homogenization for 2 min using a Ultraturrax homogenizer T25 Digital (Ika Werke GMBH \& Co. KG, Staufen, Germany), the volume was adjusted to $25 \mathrm{~mL}$. The resultant slurry was filtered through a Whatman No. 1 filter paper. $100 \mu \mathrm{L}$ of isoascorbic acid (Sigma) as internal standard $(600 \mu \mathrm{g} / \mathrm{mL})$ were added to $1.5 \mathrm{~mL}$ of the filtrate and made up to $2 \mathrm{~mL}$ with aqueous $0.2 \%$ DL-dithiotreitol, reagent used to reduce dehydroascorbic acid to ascorbic acid, mixed thoroughly and filtered through a $0.45 \mu \mathrm{m}$ membrane. Extractions were performed in triplicate. Total vitamin $\mathrm{C}$ was quantified as ascorbic acid using a calibration curve built with pure ascorbic acid standard using the response factor relative to internal standard. Vitamin C content was expressed in $\mathrm{mg} / \mathrm{g}$ dry matter (DM).

\section{Preparation of extracts for determination of total phenolic compounds content and antioxidant/reducing capacity of broccoli florets}

The extracts were prepared following the protocol described by Zielińska et al. [2008a]. Approximately $100 \mathrm{mg}$ of freeze-dried and pulverized broccoli florets were extracted with $1 \mathrm{~mL}$ of a mixture of methanol/water $(4: 1 ; \mathrm{v} / \mathrm{v})$ by sonication $(30 \mathrm{~s})$. The mixture was vortexed for $30 \mathrm{~s}$, then sonicated again and centrifuged for 5 min $\left(5000 \times g, 4^{\circ} \mathrm{C}\right)$ using a Beckman GS-15 R centrifuge (Beckman Instruments, Inc., Palo Alto, CL., U.S.A.). This step was repeated five times (the residue was each time re-suspended in $1 \mathrm{~mL}$ of $80 \%$ methanol). The supernatants were combined and collected in a $5 \mathrm{~mL}$ volumetric flask. Three independent extractions were carried out on each broccoli florets sample. Finally, extracts were kept at $-20^{\circ} \mathrm{C}$ for $2-5$ days for further determination of the total phenolic compounds (TPC), scavenging capacity against ABTS radical cations and by photochemiluminescence technique (PCL ACW), against superoxide anion radicals $\left(\mathrm{O}_{2}^{-\bullet}\right)$ and reducing capacity by cyclic voltammetry (CV) method.

\section{Determination of total phenolic compounds content (TPC)}

TPC content in the broccoli florets extracts was determined according to Shahidi \& Naczk [1995]. Briefly, $0.25 \mathrm{~mL}$ of extract was mixed with $0.25 \mathrm{~mL}$ Folin-Ciocalteu reagent, 
TABLE 1. Broccoli plant experiments using different sources of $\mathrm{N}$ in combination with Se salts.

\begin{tabular}{|c|c|c|c|c|c|c|c|c|}
\hline Treatment & $\begin{array}{c}\text { Nitrogen } \\
\text { source }\end{array}$ & $\begin{array}{c}\text { Nitrogen } \\
\text { forms }\end{array}$ & $\begin{array}{c}\text { Dose } \\
\text { (g/pot) }\end{array}$ & $\begin{array}{l}\text { Correspond } \\
\text { dose }(\mathrm{kg} / \mathrm{ha})\end{array}$ & Se salts & Se form & $\begin{array}{l}\text { Se dose } \\
(\mu \mathrm{g} / \text { pot })\end{array}$ & $\begin{array}{l}\text { Correspond } \\
\text { dose }(\mathrm{g} / \mathrm{ha})\end{array}$ \\
\hline Control & Natural & $\mathrm{N}_{2}$ & - & - & - & & - & - \\
\hline 2 & Natural & $\mathrm{N}_{2}$ & - & - & $\mathrm{Na}_{2} \mathrm{SeO}_{3}$ & $\mathrm{Se}$ (IV) & 68.78 & 10 \\
\hline 3 & Natural & $\mathrm{N}_{2}$ & - & - & $\mathrm{Na}_{2} \mathrm{SeO}_{3}$ & $\mathrm{Se}$ (IV) & 137.56 & 20 \\
\hline 4 & Natural & $\mathrm{N}_{2}$ & - & - & $\mathrm{Na}_{2} \mathrm{SeO}_{4}$ & $\mathrm{Se}(\mathrm{VI})$ & 75.15 & 10 \\
\hline 5 & Natural & $\mathrm{N}_{2}$ & - & - & $\mathrm{Na}_{2} \mathrm{SeO}_{4}$ & $\mathrm{Se}(\mathrm{VI})$ & 150.31 & 20 \\
\hline 6 & $\left(\mathrm{NH}_{4}\right)_{2} \mathrm{SO}_{4}$ & $\mathrm{NH}_{4}^{+}$ & 2.438 & 160 & - & & - & - \\
\hline 7 & $\left(\mathrm{NH}_{4}\right)_{2} \mathrm{SO}_{4}$ & $\mathrm{NH}_{4}^{+}$ & 2.438 & 160 & $\mathrm{Na}_{2} \mathrm{SeO}_{3}$ & $\mathrm{Se}(\mathrm{IV})$ & 68.78 & 10 \\
\hline 8 & $\left(\mathrm{NH}_{4}\right)_{2} \mathrm{SO}_{4}$ & $\mathrm{NH}_{4}^{+}$ & 2.438 & 160 & $\mathrm{Na}_{2} \mathrm{SeO}_{3}$ & $\mathrm{Se}(\mathrm{IV})$ & 137.56 & 20 \\
\hline 9 & $\left(\mathrm{NH}_{4}\right)_{2} \mathrm{SO}_{4}$ & $\mathrm{NH}_{4}^{+}$ & 2.438 & 160 & $\mathrm{Na}_{2} \mathrm{SeO}_{4}$ & $\mathrm{Se}(\mathrm{VI})$ & 75.15 & 10 \\
\hline 10 & $\left(\mathrm{NH}_{4}\right)_{2} \mathrm{SO}_{4}$ & $\mathrm{NH}_{4}^{+}$ & 2.438 & 160 & $\mathrm{Na}_{2} \mathrm{SeO}_{4}$ & $\mathrm{Se}(\mathrm{VI})$ & 150.31 & 20 \\
\hline 11 & $\mathrm{NaNO}_{3}$ & $\mathrm{NO}_{3}^{-}$ & 3.103 & 160 & - & & - & - \\
\hline 12 & $\mathrm{NaNO}_{3}$ & $\mathrm{NO}_{3}^{-}$ & 3.103 & 160 & $\mathrm{Na}_{2} \mathrm{SeO}_{3}$ & $\mathrm{Se}$ (IV) & 68.78 & 10 \\
\hline 13 & $\mathrm{NaNO}_{3}$ & $\mathrm{NO}_{3}^{-}$ & 3.103 & 160 & $\mathrm{Na}_{2} \mathrm{SeO}_{3}$ & Se (IV) & 137.56 & 20 \\
\hline 14 & $\mathrm{NaNO}_{3}$ & $\mathrm{NO}_{3}^{-}$ & 3.103 & 160 & $\mathrm{Na}_{2} \mathrm{SeO}_{4}$ & $\mathrm{Se}(\mathrm{VI})$ & 75.15 & 10 \\
\hline 15 & $\mathrm{NaNO}_{3}$ & $\mathrm{NO}_{3}^{-}$ & 3.103 & 160 & $\mathrm{Na}_{2} \mathrm{SeO}_{4}$ & $\mathrm{Se}(\mathrm{VI})$ & 150.31 & 20 \\
\hline 16 & $\mathrm{NH}_{4} \mathrm{NO}_{3}$ & $\mathrm{NH}_{4}^{+}+\mathrm{NO}_{3}^{-}$ & 1.506 & 160 & - & & - & - \\
\hline 17 & $\mathrm{NH}_{4} \mathrm{NO}_{3}$ & $\mathrm{NH}_{4}^{+}+\mathrm{NO}_{3}^{-}$ & 1.506 & 160 & $\mathrm{Na}_{2} \mathrm{SeO}_{3}$ & $\mathrm{Se}$ (IV) & 68.78 & 10 \\
\hline 18 & $\mathrm{NH}_{4} \mathrm{NO}_{3}$ & $\mathrm{NH}_{4}^{+}+\mathrm{NO}_{3}^{-}$ & 1.506 & 160 & $\mathrm{Na}_{2} \mathrm{SeO}_{3}$ & Se (IV) & 137.56 & 20 \\
\hline 19 & $\mathrm{NH}_{4} \mathrm{NO}_{3}$ & $\mathrm{NH}_{4}^{+}+\mathrm{NO}_{3}^{-}$ & 1.506 & 160 & $\mathrm{Na}_{2} \mathrm{SeO}_{4}$ & $\mathrm{Se}(\mathrm{VI})$ & 75.15 & 10 \\
\hline 20 & $\mathrm{NH}_{4} \mathrm{NO}_{3}$ & $\mathrm{NH}_{4}^{+}+\mathrm{NO}_{3}^{-}$ & 1.506 & 160 & $\mathrm{Na}_{2} \mathrm{SeO}_{4}$ & $\mathrm{Se}(\mathrm{VI})$ & 150.31 & 20 \\
\hline 21 & $\mathrm{CO}\left(\mathrm{NH}_{2}\right)_{2}$ & $-\mathrm{NH}_{2}$ & 1.096 & 160 & - & & - & - \\
\hline 22 & $\mathrm{CO}\left(\mathrm{NH}_{2}\right)_{2}$ & $-\mathrm{NH}_{2}$ & 1.096 & 160 & $\mathrm{Na}_{2} \mathrm{SeO}_{3}$ & $\mathrm{Se}(\mathrm{IV})$ & 68.78 & 10 \\
\hline 23 & $\mathrm{CO}\left(\mathrm{NH}_{2}\right)_{2}$ & $-\mathrm{NH}_{2}$ & 1.096 & 160 & $\mathrm{Na}_{2} \mathrm{SeO}_{3}$ & $\mathrm{Se}(\mathrm{IV})$ & 137.56 & 20 \\
\hline 24 & $\mathrm{CO}\left(\mathrm{NH}_{2}\right)_{2}$ & $-\mathrm{NH}_{2}$ & 1.096 & 160 & $\mathrm{Na}_{2} \mathrm{SeO}_{4}$ & $\mathrm{Se}(\mathrm{VI})$ & 75.15 & 10 \\
\hline 25 & $\mathrm{CO}\left(\mathrm{NH}_{2}\right)_{2}$ & $-\mathrm{NH}_{2}$ & 1.096 & 160 & $\mathrm{Na}_{2} \mathrm{SeO}_{4}$ & $\mathrm{Se}(\mathrm{VI})$ & 150.31 & 20 \\
\hline
\end{tabular}

previously diluted with distilled water $(1: 1 \mathrm{v} / \mathrm{v}), 0.5 \mathrm{~mL}$ saturated sodium carbonate $\left(\mathrm{Na}_{2} \mathrm{CO}_{3}\right)$ and $4 \mathrm{~mL}$ of water. The mixture was incubated at room temperature for $25 \mathrm{~min}$ and centrifuged at $2000 \times g$ for $10 \mathrm{~min}$. Supernatant absorbance was measured at $725 \mathrm{~nm}$ using a spectrophotometer (UV-160 1PC, Shimadzu, Tokyo, Japan). TPC was standardized against $(+)$-catechin and expressed in terms of $\mathrm{mg}$ (+)-catechin equivalents/g DM.

\section{Determination of the antioxidant capacity of broccoli florets}

\section{ABTS $^{\cdot+}$ scavenging assay}

The method described by Re et al. [1999] was used to determine the antioxidant capacity against $\mathrm{ABTS}^{\cdot+}$ radical of broccoli floret extracts. Briefly, the ABTS ${ }^{*+}$ solution was diluted with a mixture of methanol/water $(4: 1 ; \mathrm{v} / \mathrm{v})$, to the absorbance level of $0.70 \pm 0.02$ at $734 \mathrm{~nm}$. For the spec- trophotometric assay, $1.48 \mathrm{~mL}$ of the $\mathrm{ABTS}^{\cdot+}$ solution and $20 \mu \mathrm{L}$ of the respective extract or the Trolox solution were mixed, and the absorbance was measured directly after $6 \mathrm{~min}$ at $734 \mathrm{~nm}$ at $30^{\circ} \mathrm{C}$. The standard curve was plotted within the range of $0.1-2.5 \mathrm{mM}$ of Trolox standard solutions in a mixture of methanol/water $(4: 1 ; \mathrm{v} / \mathrm{v})$. Measurements were carried out using the UV-160 1PC temperature-controlled spectrophotometer with a CPS-Controller (Shimadzu, Tokyo, Japan). The antioxidant capacity was expressed as $\mu \mathrm{mol}$ Trolox/g DM.

Superoxide radical anion $\left(\mathrm{O}_{2}{ }^{--}\right)$scavenging capacity assay

The photo-induced chemiluminescence (PCL) assay, carried out using the method proposed by Popov \& Lewin [1999], was performed to measure the antioxidant activity of broccoli floret extracts against superoxide anion radicals $\left(\mathrm{O}_{2}{ }^{\circ}\right)$ generated from luminol, a photosensitizer, under exposure to UV light, as previously described by Zielińska et al. [2008b]. 
TABLE 2. Vitamin C content (mg/g DM) in broccoli florets cultivated with different sources of $\mathrm{N}$ in combination with Se salts.

\begin{tabular}{|c|c|c|c|c|c|}
\hline Treatment & Commercial soil (CS) & $\begin{array}{c}\mathrm{CS}+\left(\mathrm{NH}_{4}\right)_{2} \mathrm{SO}_{4} \\
160 \mathrm{Kg} \mathrm{N} / \mathrm{ha} \\
\end{array}$ & $\begin{array}{l}\mathrm{CS}+\mathrm{NaNO}_{3} \\
160 \mathrm{Kg} \mathrm{N} / \mathrm{ha} \\
\end{array}$ & $\begin{array}{c}\mathrm{CS}+\mathrm{NH}_{4} \mathrm{NO}_{3} \\
160 \mathrm{Kg} \mathrm{N} / \mathrm{ha} \\
\end{array}$ & $\begin{array}{c}\mathrm{CS}+\mathrm{CO}\left(\mathrm{NH}_{2}\right)_{2} \\
160 \mathrm{Kg} \mathrm{N} / \mathrm{ha} \\
\end{array}$ \\
\hline Control & $1.62 \pm 0.05^{\mathrm{b}}{ }_{1}$ & $1.55 \pm 0.08^{\mathrm{c}}$ & $1.62 \pm 0.03^{\mathrm{c}}{ }_{1}$ & $1.59 \pm 0.06^{\mathrm{c}}{ }_{1}$ & $1.59 \pm 0.06^{\mathrm{b}}{ }_{1}$ \\
\hline$+\mathrm{Se}(\mathrm{IV})(10 \mathrm{~g} / \mathrm{ha})$ & $1.12 \pm 0.03^{\mathrm{a}}$ & $1.08 \pm 0.03^{\mathrm{b}}{ }_{1,2}$ & $1.17 \pm 0.03^{\mathrm{b}}{ }_{3}$ & $1.05 \pm 0.03^{b}{ }_{1}$ & $1.08 \pm 0.04^{\mathrm{a}}{ }_{1,2}$ \\
\hline+ Se (IV) $(20 \mathrm{~g} / \mathrm{ha})$ & $1.07 \pm 0.02^{\mathrm{a}}{ }_{2}$ & $0.99 \pm 0.04^{\mathrm{a}}{ }_{1}$ & $1.05 \pm 0.04_{2}^{\mathrm{a}}$ & $0.97 \pm 0.01^{\mathrm{a}}{ }_{1}$ & $1.06 \pm 0.05^{\mathrm{a}}$ \\
\hline$+\mathrm{Se}(\mathrm{VI})(10 \mathrm{~g} / \mathrm{ha})$ & $1.11 \pm 0.04_{2}^{\mathrm{a}}$ & $1.08 \pm 0.06^{\mathrm{b}}{ }_{1,2}$ & $1.04 \pm 0.04^{\mathrm{a}}$ & $1.08 \pm 0.02^{\mathrm{b}}{ }_{1,2}$ & $1.10 \pm 0.03^{\mathrm{a}}{ }_{2}$ \\
\hline$+\mathrm{Se}(\mathrm{VI})(20 \mathrm{~g} / \mathrm{ha})$ & $1.11 \pm 0.03^{\mathrm{a}}$ & $1.07 \pm 0.03^{\mathrm{b}}{ }_{2,3}$ & $1.02 \pm 0.03^{\mathrm{a}}{ }_{1}$ & $1.09 \pm 0.03^{\mathrm{b}}{ }_{2,3}$ & $1.05 \pm 0.05_{1,2}^{\mathrm{a}}$ \\
\hline
\end{tabular}

Data are the mean of five independent replicates \pm SD. Similar letter as superscripts in the same column indicates no significant differences (P $\leq 0.05)$. Similar number as subscripts in the same row indicates no significant differences $(\mathrm{P} \leq 0.05)$.

The antioxidant capacity of broccoli floret extracts was determined using the ACW analytical kit for measuring the antioxidant capacity of hydrophilic compounds and a Photochem ${ }^{\circledR}$ apparatus (Analytik Jena, Leipzig, Germany). Antioxidant capacity was expressed as $\mu \mathrm{mol}$ Trolox/g DM.

\section{The cyclic voltammetry $(\mathrm{CV})$ method}

Cyclic voltammetric experiments were performed on broccoli floret extracts previously prepared and mixed with $0.1 \mathrm{M}$ sodium acetate-acetic buffer $(\mathrm{pH} 5.5)$ at a ratio of $1: 1(\mathrm{v} / \mathrm{v})$, according to Zieliński et al. [2012]. The sodium acetate-acetic buffer acted as a supporting electrolyte of extracts for the voltammetric determinations. The measurements were carried out using a conventional three electrode system: (a) a $3 \mathrm{~mm}$ diameter glassy carbon working electrode (BAS MF-2012), (b) a Ag/AgCl electrode as reference one, and (c) a platinum electrode as counter electrode. In order to avoid the diminishing of sensitivity, the working electrode was carefully polished with $0.05 \mu \mathrm{m}$ alumina paste purchased in BAS (Bioanalytical Systems Inc.) and ultrasonically rinsed in deionized water and methanol at the end of each cycle. The experiments were performed at room temperature. Cyclic voltammograms were recorded by potentiostat/galvanostat (GAMRY, Warminster, PA, USA) within the range of +100 to $+1100 \mathrm{mV}$ scanning rate. This method is based on the correlation between the total charge below anodic wave of cyclic voltammograms and the antioxidant capacity of the sample and reference substance. The $80 \%$ methanol solutions of Trolox within the concentration range of $0.05-1.25 \mathrm{mM}$ were used. The total charge under anodic wave of the background signal (solvent + supporting electrode) was subtracted from total charge under anodic wave obtained for each standard and sample. Results were expressed as $\mu \mathrm{mol}$ Trolox/g DM.

\section{Statistical analyses}

Results of the chemical analyses are given as mean values and the standard deviation of five independent broccoli florets determined in triplicates. The results were subjected to two-way analysis of variance (ANOVA) using Fisher's Least Significant Difference (LSD) test and the significant differences $(P \leq 0.05)$ were calculated. Correlation analysis was also performed and the Pearson correlation coefficient was reported using the Statistica 7.1.30.0 software (Statsoft Inc., USA) for Windows.

\section{RESULTS AND DISCUSSION}

\section{The influence of $\mathbf{N}$ treatment in combination with Se on vitamin $\mathbf{C}$ content in broccoli florets}

Table 2 shows the content of vitamin $\mathrm{C}$ in broccoli florets cultivated in soil with different inorganic $\mathrm{N}$ forms combined with Se (IV) and Se (VI). No significant $(\mathrm{P}>0.05)$ differences were found in vitamin $\mathrm{C}$ content between broccoli florets cultivated in untreated soil and those fortified with the experimental N-sources at $160 \mathrm{Kg} \mathrm{N} / \mathrm{ha}$. Vitamin C content in these broccoli florets ranged between 1.55 and $1.62 \mathrm{mg} / \mathrm{g}$ DM and minimal changes could be due to different bioavailability of N sources. Similar results were obtained by Elwan \& Abd El Hamed [2011] who did not found any influence of nitrogen application on vitamin $\mathrm{C}$ in different broccoli varieties.

Broccoli cultivation in soil only enriched with Se (IV) and Se (VI) at the level corresponding to 10 or $20 \mathrm{~g} \mathrm{Se} / \mathrm{ha}$ led to a significant $(\mathrm{P} \leq 0.05)$ decrease in vitamin $\mathrm{C}$ (by average $33 \%$ ) when compared to cultivation in control soils. The influence of the two doses of Se (IV) combined with the different $\mathrm{N}$ sources on vitamin $\mathrm{C}$ content was noted for those broccoli florets cultivated in the presence of $\left(\mathrm{NH}_{4}\right)_{2} \mathrm{SO}_{4}$, $\mathrm{NaNO}_{3}$ and $\mathrm{NH}_{4} \mathrm{NO}_{3}$, where the application of $20 \mathrm{~g} \mathrm{Se} /$ ha led to a larger vitamin $\mathrm{C}$ decrease. However, no significant differences $(\mathrm{P}>0.05)$ were observed between the two Se (VI) doses combined with inorganic $\mathrm{N}$ on vitamin $\mathrm{C}$ content of broccoli. To the best of our knowledge, no information about the effect of combining $\mathrm{N}$ and $\mathrm{Se}$ has been reported in literature so far. In general, this study shows that broccoli cultivation with Se-enriched soil led to a sharp vitamin $\mathrm{C}$ decrease in broccoli florets, irrespective of $\mathrm{N}$ enriched soils.

\section{The influence of $\mathbf{N}$ treatment in combination with $\mathrm{Se}$ on total phenolic compounds content in broccoli florets}

Table 3 shows the content of total phenolic compounds (TPC) in broccoli florets cultivated in different $\mathrm{N}$ inorganic sources in combination with $\mathrm{Se}$ (IV) and Se (VI). Florets produced under $\mathrm{N}$ at $160 \mathrm{Kg} \mathrm{N} /$ ha showed TPC content being significantly $(\mathrm{P} \leq 0.05)$ higher $(\sim 45 \%)$ than those cultivated in untreated soil, ranging between 9.22 to $10.46 \mathrm{mg}$ (+)-catechin/g DM, and $\mathrm{NH}_{4} \mathrm{NO}_{3}$ enriched soil was the largest TPC producer. These results agree with those previously reported by Zaghdoud et al. [2016] where $\mathrm{NH} 4^{+}$-fed broccoli had higher levels of total phenolic compounds. When 
TABLE 3. Content of total phenolic compounds $(\mathrm{mg}(+)$-catechin/g DM) in broccoli florets cultivated with different sources of $\mathrm{N}$ in combination with Se salts.

\begin{tabular}{lccccc|c}
\hline Treatment & Commercial soil (CS) & $\begin{array}{c}\mathrm{CS}+\left(\mathrm{NH}_{4}\right)_{2} \mathrm{SO}_{4} \\
160 \mathrm{Kg} \mathrm{N} / \mathrm{ha}\end{array}$ & $\begin{array}{c}\mathrm{CS}+\mathrm{NaNO}_{3} \\
160 \mathrm{Kg} \mathrm{N} / \mathrm{ha}\end{array}$ & $\begin{array}{c}\mathrm{CS}+\mathrm{NH}_{4} \mathrm{NO}_{3} \\
160 \mathrm{Kg} \mathrm{N} / \mathrm{ha}\end{array}$ & $\begin{array}{c}\mathrm{CS}+\mathrm{CO}(\mathrm{NH})_{2} \\
160 \mathrm{Kg} \mathrm{N} / \mathrm{ha}\end{array}$ \\
\hline Control & $6.36 \pm 0.52^{\mathrm{a}}{ }_{1}$ & $9.33 \pm 0.96^{\mathrm{c}}{ }_{3}$ & $7.77 \pm 0.18^{\mathrm{b}}{ }_{2}$ & $10.46 \pm 0.43^{\mathrm{cd}}{ }_{3}$ & $9.22 \pm 0.13^{\mathrm{c}}$ \\
$+\mathrm{Se}(\mathrm{IV})(10 \mathrm{~g} / \mathrm{ha})$ & $5.95 \pm 0.53^{\mathrm{a}}{ }_{1,2}$ & $5.43 \pm 0.36^{\mathrm{a}}{ }_{1}$ & $8.60 \pm 0.23^{\mathrm{c}}{ }_{3}$ & $11.26 \pm 0.06^{\mathrm{d}}{ }_{4}$ & $7.06 \pm 0.89^{\mathrm{b}}{ }_{2}$ \\
$+\mathrm{Se}(\mathrm{IV})(20 \mathrm{~g} / \mathrm{ha})$ & $6.77 \pm 0.12^{\mathrm{ab}}{ }_{1}$ & $8.12 \pm 0.38^{\mathrm{bc}}{ }_{2}$ & $9.13 \pm 0.32^{\mathrm{c}}{ }_{3}$ & $7.52 \pm 0.58^{\mathrm{b}}{ }_{1,2}$ & $9.38 \pm 0.06^{\mathrm{c}}{ }_{3}$ \\
+ Se (VI) (10 g/ha) & $9.44 \pm 0.21^{\mathrm{c}}{ }_{2}$ & $7.17 \pm 0.26^{\mathrm{b}}{ }_{1}$ & $6.97 \pm 0.26^{\mathrm{a}}{ }_{1}$ & $9.71 \pm 0.08^{\mathrm{c}}{ }_{2}$ & $6.77 \pm 0.37^{\mathrm{ab}}{ }_{1}$ \\
+ Se (VI) (20 g/ha) & $7.20 \pm 0.88^{\mathrm{b}}{ }_{2}$ & $9.37 \pm 0.16^{\mathrm{c}}{ }_{3}$ & $7.31 \pm 0.38^{\mathrm{ab}}{ }_{2}$ & $6.23 \pm 0.16^{\mathrm{a}}{ }_{1,2}$ & $5.84 \pm 0.23^{\mathrm{a}}{ }_{1}$ \\
\hline
\end{tabular}

Data are the mean of five independent replicates \pm SD. Similar letter as superscripts in the same column indicates no significant differences $(\mathrm{P} \leq 0.05)$. Similar number as subscripts in the same row indicates no significant differences $(\mathrm{P} \leq 0.05)$.

Se (IV) was applied, no significant $(\mathrm{P}>0.05)$ impact on TPC content was found, irrespective of Se concentration, in comparison with the unfortified soil. In contrast, Se (VI) addition led to florets with significantly $(\mathrm{P} \leq 0.05)$ higher TPC content (48 and 13\% for 10 and $20 \mathrm{~g} \mathrm{Se} / \mathrm{ha}$, respectively). When various sources of $\mathrm{N}$ were applied in combination with Se (IV) and Se (VI), a different effect on TPC content of broccoli florets was observed. A higher TPC content was found for 10 and $20 \mathrm{~g} \mathrm{Se}$ (IV)/ha with $\mathrm{NaNO}_{3}$ and 11 and $18 \%$, respectively, was obtained in comparison with TPC content in broccoli florets grown only in $\mathrm{NaNO}_{3}$ cultivated soil. The combination of $10 \mathrm{~g} \mathrm{Se} /$ ha with $\mathrm{NH}_{4} \mathrm{NO}_{3}$ caused an $8 \%$ increase in TPC content compared with the non-Se counterpart. Other combinations of Se (IV) with the remaining N sources and the Se (VI) with all $\mathrm{N}$-forms did not improve the content of TPC in broccoli florets. In most experiments, TPC content was slightly lower than those observed in the corresponding florets without Se enrichment. These results suggest that Se uptake influences TPC content of broccoli florets depending on the salt/amount of Se and on N source, outcomes observed here for the first time. Nevertheless, at the current stage of this study, it can be stated that the condition to provide the highest TPC content in broccoli florets was achieved combining NH${ }_{4} \mathrm{NO}_{3}$ with the low Se (IV) dose (11.26 mg catechin/g DM).

\section{The influence of $\mathbf{N}$ treatment in combination with $\mathrm{Se}$ on the antioxidant and reducing capacities of broccoli florets provided by ABTS, PCL and CV assays}

In this study, the antioxidant capacity in florets of broccoli grown in soil enriched with different sources of $\mathrm{N}$ in combination with two concentrations of Se (IV) and Se (VI) was determined according to the different assays. Antioxidant capacity was determined: i) against stable, non-biological relevant $\mathrm{ABTS}^{\cdot+}$, ii) against the key oxygen reactive form, e.g. $\mathrm{O}_{2} \cdot$ by photochemiluminescence (PCL ACW), and iii) directly by cyclic voltammetry (CV) as reducing capacity. From the current point of view, this set of in vitro methods should be used as a tool for the determination of antioxidant activity of food to cover the most relevant aspects of antioxidant efficacy [Zieliński et al., 2012]. The ABTS assay is a renowned method and used as Trolox Equivalent Antioxidant Capacity (TEAC). The photochemiluminescence assay (PLC), based on the photochemical generation of free radicals combined with enhanced sensitivity of chemiluminescence, uses the pho- to-induced autoxidation inhibition of luminol by antioxidants mediated by $\mathrm{O}_{2}{ }^{-}$and is suitable in measuring the radical scavenging properties of single antioxidants as well as more complex food systems at the nanomolar range [Besco et al., 2007]. The CV technique has shown to be a convenient assay for evaluating the reducing capacity of raw plant material as well as food products [Zielińska et al., 2008b; Zieliński et al., 2012]. Cyclic voltammogram (CV tracing) provides direct information describing the integral reducing capacity without the specific determination of individual components since the anodic current waveform obtained is a function of the reducing potential of a mixture of components.

Figure 1 shows the antioxidant capacity of broccoli florets evaluated by ABTS assay. Broccoli florets cultivated in untreated soil reached levels of antioxidant capacity of $45 \mu \mathrm{mol}$ Trolox/g DM while those grown in the presence of experimental $\mathrm{N}$ sources at $160 \mathrm{Kg} \mathrm{N} / \mathrm{ha}$ exhibited a significantly $(\mathrm{P} \leq 0.05)$ higher antioxidant capacity ( $\sim 41 \%$ increase). The greatest antioxidant capacity was observed in the broccoli florets cultivated in soil containing $\mathrm{NH}_{4} \mathrm{NO}_{3}$. A positive influence of Se (IV) fortification on the antioxidant capacity of broccoli florets was noted in most cases. Application of Se (VI) at

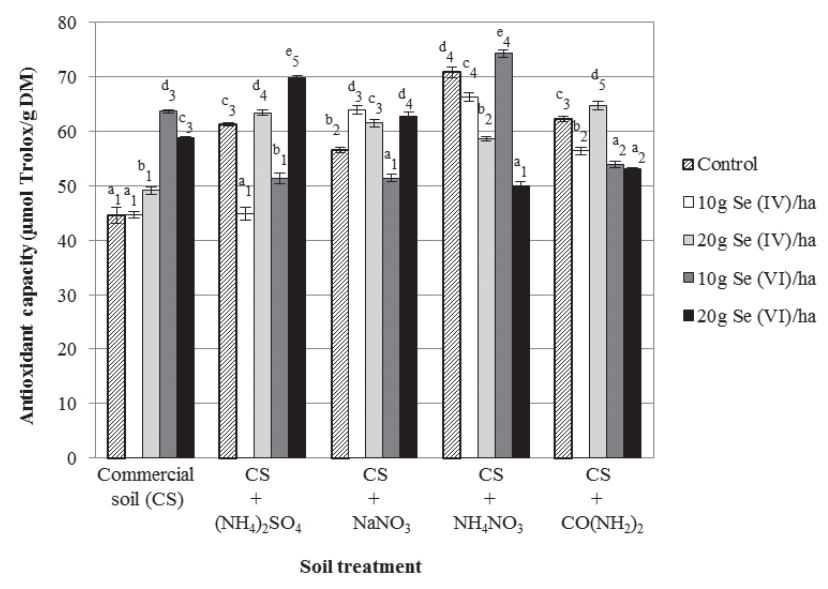

FIGURE 1. Antioxidant capacity in broccoli florets cultivated with different inorganic $\mathrm{N}$ sources in combination with Se salts determined by ABTS assay. Data are the mean of five independent replicates \pm SD. Similar letter as superscripts for the same $\mathrm{N}$ treatment indicates no significant differences $(\mathrm{P} \leq 0.05)$. Similar number as subscripts for the same Se treatment indicates no significant differences $(\mathrm{P} \leq 0.05)$. 


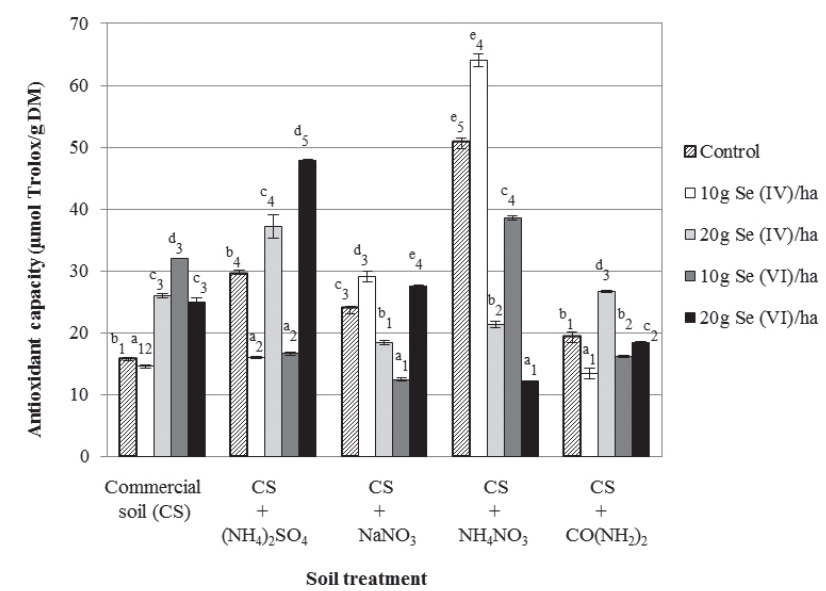

FIGURE 2. Antioxidant capacity formed by water-soluble antioxidants in broccoli florets cultivated with inorganic $\mathrm{N}$ sources in combination with Se salts determined by PCL ACW assay. Data are the mean of five independent replicates \pm SD. Similar letter as superscripts for the same $\mathrm{N}$ treatment indicates no significant differences $(\mathrm{P} \leq 0.05)$. Similar number as subscripts for the same Se treatment indicates no significant differences $(\mathrm{P} \leq 0.05)$.

either 10 or $20 \mathrm{~g} \mathrm{Se} /$ ha provided a higher antioxidant capacity, i.e. increment of 43 and 32\%, compared to control soil. When various $\mathrm{N}$ salts were combined with Se (IV) or Se (VI), a different effect on the antioxidant capacity was observed. Se (IV) increased antioxidant capacity evaluated by ABTS •+ assay in florets only in combination with $\mathrm{NaNO}_{3}$, irrespective of Se concentration, and with $\mathrm{CO}\left(\mathrm{NH}_{2}\right)_{2}$ at $20 \mathrm{~g} \mathrm{Se} / \mathrm{ha}$. In turn, application of $20 \mathrm{~g} \mathrm{Se}(\mathrm{VI}) /$ ha with $\left(\mathrm{NH}_{4}\right)_{2} \mathrm{SO}_{4}$ or $\mathrm{NaNO}_{3}$ and $10 \mathrm{~g}$ Se (VI)/ha with $\mathrm{NH}_{4} \mathrm{NO}_{3}$ provided broccoli florets with a slightly, but statistically significant $(\mathrm{P} \leq 0.05)$ higher antioxidant capacity as compared to corresponding $\mathrm{N}$ soils without Se salt.

Figure 2 shows the antioxidant capacity of hydrophilic compounds of broccoli florets evaluated by PCL ACW assay. The application of $\mathrm{N}$ caused a favourable effect in all the experimental broccoli florets and enhanced their antioxidant capacity, which ranged from 19 to $51 \mu \mathrm{mol}$ Trolox/g DM, compared with those cultivated only in untreated soil (16 $\mu \mathrm{mol}$ Trolox/g DM). The highest antioxidant capacity was achieved with $\mathrm{NH}_{4} \mathrm{NO}_{3}$ treatment, as previously observed by ABTS test. The antioxidant capacity increased by 65,103 and $58 \%$ in florets grown with $20 \mathrm{~g} \mathrm{Se}$ (IV)/ha and with 10 and $20 \mathrm{~g} \mathrm{Se}$ (VI)/ha, respectively, compared to these grown in unfertilized soil. Combination of Se salts with $\mathrm{N}$ inorganic sources brought about different effect on this antioxidant capacity in broccoli florets. Se (IV) at $10 \mathrm{~g} / \mathrm{ha} \mathrm{com-}$ bined with $\mathrm{NaNO}_{3}$ and $\mathrm{NH}_{4} \mathrm{NO}_{3}$ and at $20 \mathrm{~g} \mathrm{Se} /$ ha added to $\left(\mathrm{NH}_{4}\right)_{2} \mathrm{SO}_{4}$ and $\mathrm{CO}\left(\mathrm{NH}_{2}\right)_{2}$ soils caused a significant $(\mathrm{P} \leq 0.05)$ increase in the antioxidant capacity of broccoli florets. Similar tendency was found for $10 \mathrm{~g} \mathrm{Se}(\mathrm{VI}) / \mathrm{ha}$ combined with $\mathrm{NH}_{4} \mathrm{NO}_{3}$ and $20 \mathrm{~g}$ Se (VI)/ha with $\mathrm{NaNO}_{3}$ soils. The largest antioxidant capacity against $\mathrm{O}_{2}{ }^{-}$radicals was provided by $\mathrm{NH}_{4} \mathrm{NO}_{3}$ combined with $10 \mathrm{~g} \mathrm{Se}$ (IV)/ha supplemented soils (64 $\mu \mathrm{mol}$ Trolox/g DM).

Figure 3 shows the reducing capacity of broccoli florets evaluated by $\mathrm{CV}$ method. The obtained results were in the line

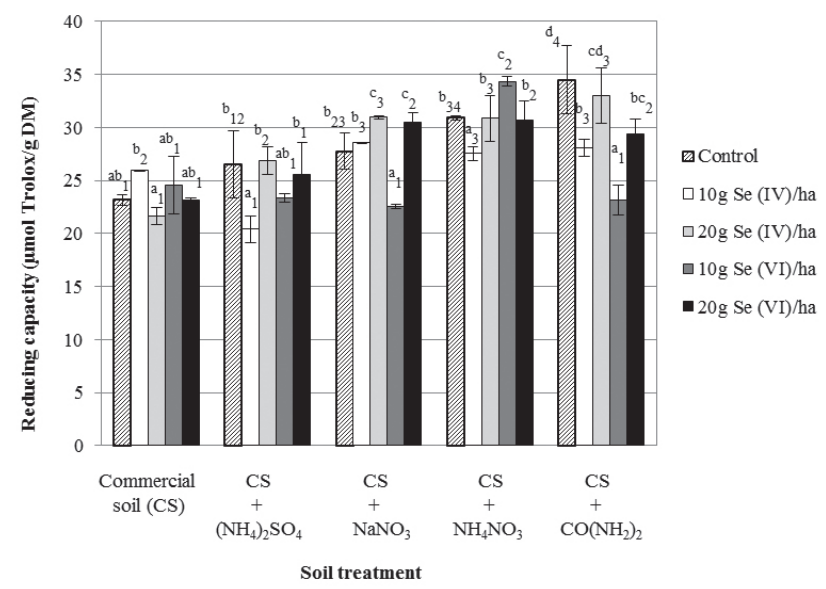

FIGURE 3. Reducing capacity of broccoli florets cultivated with different inorganic $\mathrm{N}$ sources in combination with Se salts determined by cyclic voltammetry $(\mathrm{CV})$ method. Data are the mean of five independent replicates \pm SD. Similar letter as superscripts for the same $\mathrm{N}$ treatment indicates no significant differences $(\mathrm{P} \leq 0.05)$. Similar number as subscripts for the same Se treatment indicates no significant differences $(\mathrm{P} \leq 0.05)$.

with those found for ABTS and PCL ACW assays since inorganic $\mathrm{N}$ application fostered the reducing capacity of florets (26-34 $\mu \mathrm{mol}$ Trolox/g DM against $23 \mu \mathrm{mol}$ Trolox/g DM for the control ones). The highest reducing capacity was achieved in broccoli grown in $\mathrm{CO}\left(\mathrm{NH}_{2}\right)_{2}$, soil. Se-salts did not significantly $(\mathrm{P}>0.05)$ improve the reducing capacity compared to the untreated soil. Combination of Se (IV) and Se (VI) at 10 and $20 \mathrm{~g} /$ ha with the experimental $\mathrm{N}$ salts produced a different effect on reducing the capacity in broccoli florets. Se (IV) increased slightly the reducing capacity at $20 \mathrm{~g} \mathrm{Se} / \mathrm{ha}$ mixed with $\mathrm{NaNO}_{3}$, as well as Se (VI) at $10 \mathrm{~g} /$ ha with $\mathrm{NH}_{4} \mathrm{NO}_{3}$ and $20 \mathrm{~g} /$ ha with $\mathrm{NaNO}_{3}$.

There is scarce information on the effect of the application of N and Se during broccoli growth. Mahn [2017] demonstrated that the increase in Se dose from 10 to $100 \mu \mathrm{mol} / \mathrm{L}$ produced a significant decrease in the antioxidant properties of broccoli florets.

The antioxidant capacity of broccoli florets evaluated against $\mathrm{ABTS}^{\cdot+}$ was positively correlated with that resulting from PCL $\mathrm{ACW}$ assay $(\mathrm{r}=0.75)$ and from $\mathrm{CV}$ technique $(\mathrm{r}=0.60)$. However, a lack of correlation was found between PCL ACW and CV assays $(r=0.20)$. No correlations between vitamin $C$ content and antioxidant capacity determined either by ABTS or PCL $\mathrm{ACW}$ assays or reducing capacity $(\mathrm{CV})$ was found. In contrast, total phenolic content was positively correlated with antioxidant capacity determined by ABTS $(r=0.87)$, PCL ACW $(r=0.80)$ and $\mathrm{CV}(\mathrm{r}=0.48)$. These findings indicate the relevant role of phenolic compounds and the minor significance of vitamin $\mathrm{C}$ in the overall antioxidant capacity of broccoli florets. Moreover, both ABTS and PCL ACW assays use scavenging of free radicals with different chemical properties as compared to cyclic voltammetry $(\mathrm{CV})$ technique, which is especially useful for the evaluation of the reducing capacity formed by low molecular weight antioxidants.

Reducing capacity of broccoli florets cultivated with various $\mathrm{N}$ treatments in combination with Se provided by $\mathrm{CV}$ 
assay (Figure 3) was comparable to the antioxidant capacity values obtained by PCL ACW assay (Figure 2). However, reducing capacity was 2 -fold lower than values provided by ABTS method (Figure 1). These findings confirm the previously found rank of antioxidant capacity assays applied for the characterization of new crispy type food products [Zieliński et al., 2012] and buckwheat and lupine sprouts [Zielińska et al., 2008a,b]. The results may also indicate that broccoli florets grown under different $\mathrm{N}$ treatments in combination with selected doses of Se (IV) and Se (VI) produce more free radical scavengers than electroactive substances. It was reported that treatments with $\mathrm{N}$ in excessive application can result in undesirable changes such as increases in nitrate and acid to sugar ratio, while decreasing the concentration of vitamin $\mathrm{C}$, soluble sugar and $\mathrm{Mg}$ and $\mathrm{Ca}$ [Wang et al., 2008]. Research literature on this subject suggests that more information is required to produce broccoli florets with a higher content of phenolic compounds and antioxidant capacity.

\section{CONCLUSIONS}

The application of inorganic $\mathrm{N}$ sources combined with $\mathrm{Se}$ during the growth of broccoli florets has a different impact on vitamin $\mathrm{C}$, total phenolic content, and antioxidant capacity. The treatment with $\mathrm{N}$ salts did not affect vitamin $\mathrm{C}$ content however provided a higher total phenolics content and antioxidant capacity than the untreated soil. The combination with Se salts (IV or VI) decreased vitamin C content of broccoli florets, irrespective of $\mathrm{N}$ source, whilst phenolics content and antioxidant capacities varied depending on $\mathrm{N}$ source and Se dose. Among all the experimental treatments, application of $\mathrm{NH}_{4} \mathrm{NO}_{3}$ in combination with $10 \mathrm{~g} \mathrm{Se}$ (IV)/ha was the elective strategy to produce broccoli florets with a higher total phenolic content providing, at the same time, high levels of antioxidant capacity and relevant amounts of vitamin $\mathrm{C}$. In addition, a pot of edible broccoli ( $100 \mathrm{~g}$ fresh weight) grown in these conditions provided $40 \mu \mathrm{g}$ Se [Gulewicz, unpublished data] that would contribute to Se requirements in adults, taking in mind that daily intake of about $1 \mu \mathrm{g} \mathrm{Se} / \mathrm{kg}$ body weight has been recommended [WHO, 1996].

\section{ACKNOWLEDGEMENTS}

E. Peñas acknowledges the MINECO and European Social Fund for her "Ramón y Cajal" contract.

\section{RESEARCH FUNDING}

This work was supported by the Ministry of Economy and Competitiveness (MINECO, Spain) and FEDER programme from the European Commission (grant number AGL2013-43247-R) and by the National Science Center (Poland) (grant No. 5056/B/P01/2011/40).

\section{REFERENCES}

1. Abou El-Magd M.M., Sawan O.M., Zaki M.F., Abb Elall F.S., Productivity and quality of two broccoli cultivars as affected by different levels of nitrogen fertilisers. Austral. J. Basic. Appl. Sci., 2010, 6, 6125-6133.

2. Avato P., Argentieri M.P., Brassicaceae: a rich source of health improving phytochemicals. Phytochem Rev., 2015, 14, 1019-1033.

3. Besco E., Braccioli E., Vertuani S., Ziosi P., Brazzo F., Bruni R., Sacchetti G., Manfredini S., The use of photochemiluminescence for the measurement of the integral antioxidant capacity of baobab products. Food Chem., 2007, 102, 1352-1356.

4. Domínguez-Perles R., García-Viguera C., Moreno D.A., Brassica foods as a dietary source of vitamin C: a review. Crit. Rev. Food Sci. Nutr., 2014, 54, 1076-1091.

5. Ducsay L., Ložek O., Varga L., The influence of selenium soil application on its content in spring wheat. Plant Soil Env., 2009, 55, 80-84.

6. Elwan M.W.M., Abd El Hamed K.E., Influence of nitrogen form, growing season and sulfur fertilization on yield and the content of nitrate and vitamin C of broccoli. Sci. Hort., 2011, 127, 181-187.

7. Finley J.W., Reduction of cancer risk by consumption of selenium-enriched plants: Enrichment of broccoli with selenium increases the anticancerogenic properties of broccoli. J. Med. Food, 2003, 6, 19-26.

8. Frias J., Miranda L.M., Doblado R., Vidal-Valverde C., Effect of germination and fermentation on the antioxidant vitamin content and antioxidant capacity of Lupinus albus L. var. multolupa. Food Chem., 2005, 92, 211-205.

9. Germ M., Stibil J., Kreft I., Metabolic importance of selenium for plants. Eur. J. Plant Sci. Biotechnol., 2007, 1, 91-97.

10. Guerrero-Beltrán C.E., Calderón M., Pedraza-Chaverri J., Chirino Y.I., Protective effect of sulforaphane against oxidative stress: recent advances. Exp. Tox. Patholog., 2012, 64, 503-508.

11. Harris E.D., Regulation of antioxidant enzymes. FASEB J., 1992, 6, 2675-2683

12. Jeffery E.H., Araya M., Physiological effects of broccoli consumption. Phytochem. Rev., 2009, 8, 283-298.

13. Lyi S.M., Heller L.I., Rutzke M., Welch R.M., Kochian L.V., Li L., Molecular and biochemical characterization of the selenocysteineSe-methyltransferase gene and Se-methylselenocysteine synthesis in broccoli. Plant Physiol., 2005, 138, 409-420.

14. Mahn A., Modelling of the effect of selenium fertilization on the content of bioactive compounds in broccoli heads. Food Chem., 2017, 233, 492-499.

15. Mahn A., Zamorano M., Barrientos H., Reyes A., Optimization of a process to obtain selenium-enriched free-dried broccoli with high antioxidant properties. LWT - Food Sci. Technol., 2012, 47, 267-273.

16. Manzi F., Flood V., Webb K., Mictchell P., The intake of carotenoids in an older Australian population: The Blue Mointain Eye Study. Publ. Health Nutr., 2002, 5, 347-352.

17. McKillop D.J., Pentieva K., Daly D., McPartlin J.M., Hughes J., Strain J.J., Scott J.M., McNulty H., The effect of different cooking methods on folate, retention in various foods that are amongst the major contributors to folate intake in the UK diet. Brit. J. Nutr., 2002, 88, 681-688.

18. Michalska A., Wojdyło A., Bogucka B., The influence of nitrogen and potassium fertilisation on the content of polyphenolic compounds and antioxidant capacity of coloured potato. J. Food Comp. Anal., 2016, 47, 69-75.

19. Mora M.L., Pinilla L., Rosas A., Cartes P., Selenium uptake and its influence on the antioxidative system of white clover as 
affected by lime and phosphorus fertilization. Plant Soil, 2008, 303, 139-149.

20. Moreno D.A., Carvajal M., Lopez-Berenguer C., Garcia-Viguera C., Chemical and biological characterization of nutraceutical compounds of broccoli. J. Pharm Biomed. Anal., 2006, 41, $1508-1522$.

21. Omirou M.D., Papadopoulou K.K., Papastylianou M.C., Karpouzas D.G., Asimakopoulos I., Ehaliotis C., Impact of nitrogen and sulfur fertilization on the composition of glucosinolates in relation to sulfur assimilation in different plant organs of broccoli. J. Agric. Food Chem., 2009, 57, 9408-9417.

22. Pedrero Z., Elvira D., Cámara C., Madrid Y., Selenium transformation studies during broccoli (Brassica oleracea) growing process by liquid chromatography-inductively coupled plasma mass spectrometry (LC-ICP-MS). Anal. Chim. Acta, 2007, 596, 251-256.

23. Peñas E., Martinez-Villaluenga C., Frias J., Sánchez-Martínez M.J., Pérez-Corona M.T., Madrid Y., Camara C., Vidal-Valverde C., Se improves indole glucosinolate hydrolysis products content, Se-methylselenocysteine content, antioxidant capacity and anti-inflammatory properties of sauerkraut. Food Chem., 2012, 132, 907-914.

24. Popov I., Lewin G., Antioxidative homeostasis: Characterisation by means of chemiluminescent technique in methods in enzymology. 1999, in: Oxidants and Antioxidants (ed. L. Packer), part B, vol. 300, Academic Press, pp. 96-100.

25. Proteggente A.R., Pannala A.S., Paganga G., Van Buren L., Wagner E., Wiseman S., Van De P.F., Dacombe C., Rice-Evans C.A., The antioxidant activity of regularly consumed fruit and vegetables reflects their phenolic and vitamin C composition. Free Rad. Res. 2002, 36, 217-233.

26. Rayman M.P., Food-chain selenium and human health emphasis on intake. Brit. J. Nutr., 2008, 100, 254-268.

27. Re R., Pellegrini N., Proteggente A., Pannala A., Yang M., Rice-Evans C., Antioxidant activity applying an improved ABTS radical cation decolorization assay. Free Rad. Biol. Med., 1999, 26, 1291-1237.

28. Robbins R.J., Keck A.-S., Banuelos G., Finley J.W., Cultivation conditions and selenium fertilization alter the phenolic profile, glucosinolate, and sulforaphane content of broccoli. J. Med. Food, 2005, 8, 204-214.
29. Shahidi F., Naczk M., Methods of analysis and quantification of phenolic compounds. 1995, in. Food Phenolic: Sources, Chemistry, Effects and Applications (eds. F. Shahidi, M. Naczk). Lancaster/ Pensylvania: Technomic Publishing Company, pp. 287-293.

30. Staugaitis G., Viskelis P., Venskutonis P.R., Optimization of application of nitrogen fertilizars to increase the yield and improve the quality of Chinese cabbage heads. Acta Agric. Scandi. Soil Plant Sci., 2008, 58, 176-181.

31. Talalay P., Fahey J.W., Phytochemicals from cruciferous plants protect against cancer by modulating carcinogen metabolism. J. Nutr., 2001, 131, 3027S-3033S.

32. USDA. 2015. National Agricultural Statistics Service: National Statistics for Broccoli. United States Department of Agriculture [http://col.st/8tWIX].

33. Wang Z-H., Li S-X., Malhi S., Effect of fertilization and other agronomic measures on nutritional quality of crops. J. Sci. Food Agric., 2008, 88, 7-23.

34. WHO, Trace elements in human nutrition and health. World Health Organization. 1996. Geneva.

35. Zaghdoud C., Carvajal M., Moreno D.A., Ferchichi A., Martínez-Ballesta M.C., Health-promoting compounds of broccoli (Brassica oleracea L. var. italica) plants as affected by nitrogen fertilization in projected future climatic change environments. J. Sci. Food Agric., 2016, 96, 392-403.

36. Zielińska D., Frias J., Piskuła M.K., Kozłowska H., Zieliński H., Vidal-Valverde C., Evaluation of the antioxidant capacity of lupin sprouts produced with presence of selenium. Eur. Food Res. Technol., 2008a, 227, 1711-1720.

37. Zielińska D., Wiczkowski W., Piskuła M.K., Evaluation of photochemiluminescent, spectrophotometric and cyclic voltammetry methods for the measurement of the antioxidant capacity: the case of roots separated from buckwheat sprouts. Pol. J. Food Nutr. Sci., 2008b, 58, 65-72.

38. Zieliński H., Zielińska D., Kostyra H., Antioxidant capacity of a new crispy type food products determined by updated analytical strategies. Food Chem., 2012, 130, 1098-1104.

Submitted: 3 March 2017. Revised: 26 June and 28 July 2017. Accepted 28 July 2017. Published on-line: 6 November 2017. 